\title{
Ultrastructural Aspects of Photodynamic Inactivation of Highly Pathogenic Avian H5N8 Influenza Virus
}

\author{
Denis Korneev ${ }^{1, *} \mathbb{0}$, Olga Kurskaya ${ }^{2}$, Kirill Sharshov ${ }^{2}$, Justin Eastwood ${ }^{1}$ \\ and Marina Strakhovskaya ${ }^{3,4}$ (D) \\ 1 School of Biological Sciences, Monash University, 25 Rainforest Walk, Clayton, VI 3800, Australia; \\ sci-biol-enquiries@monash.edu \\ 2 Federal Research Center of Fundamental and Translational Medicine (CFTM), 630117 Novosibirsk, Russia; \\ director@centercem.ru \\ 3 Department of Biophysics, Faculty of Biology, M.V. Lomonosov Moscow State University, \\ 119991 Moscow, Russia; info@mail.bio.msu.ru \\ 4 Federal Research and Clinical Center of Specialized Medical Care and Medical Technologies, FMBA, \\ 115682 Moscow, Russia; info@fnkc-fmba.ru \\ * Correspondence: denis.korneev@monash.edu
}

Received: 13 August 2019; Accepted: 15 October 2019; Published: 16 October 2019

\begin{abstract}
Ultrastructural studies revealing morphological differences between intact and photodynamically inactivated virions can point to inactivation mechanisms and molecular targets. Using influenza as a model system, we show that photodynamic virus inactivation is possible without total virion destruction. Indeed, irradiation with a relatively low concentration of the photosensitizer (octacationic octakis(cholinyl) zinc phthalocyanine) inactivated viral particles (the virus titer was determined in Madin Darby Canine Kidney (MDCK) cells) but did not destroy them. Transmission electron microscopy (TEM) revealed that virion membranes kept structural integrity but lost their surface glycoproteins. Such structures are known as "bald" virions, which were first described as a result of protease treatment. At a higher photosensitizer concentration, the lipid membranes were also destroyed. Therefore, photodynamic inactivation of influenza virus initially results from surface protein removal, followed by complete virion destruction. This study suggests that photodynamic treatment can be used to manufacture "bald" virions for experimental purposes. Photodynamic inactivation is based on the production of reactive oxygen species which attack and destroy biomolecules. Thus, the results of this study can potentially apply to other enveloped viruses and sources of singlet oxygen.
\end{abstract}

Keywords: influenza; H5N8; photodynamic inactivation; photosensitizer; transmission electron microscopy

\section{Introduction}

Photodynamic inactivation (PDI) can be used to destroy pathogenic microorganisms including bacteria, viruses, fungi, and protozoa [1-3] which has practical applications for virus-associated lesions treatment [4] and the disinfection of water [5] or blood products [6]. The PDI technique works by exposing microorganisms to a photosensitizer which, when irradiated with the spectral region corresponding to the photosensitizer absorption bands, converts molecular oxygen into toxic reactive oxygen species (ROS). Inactivation then occurs as a result of the destructive action of ROS produced by the photosensitizer in a photoexcited state.

Enveloped viruses (e.g., Influenza viruses, Hunan Immunodeficiency Virus, and Herpes Simplex Virus) can be inactivated by various photosensitizers, including methylene blue [7], merocyanine 
540 [8], hypericin and Rose bengal [9], porphyrins [10], and phthalocyanines [11,12]. Although all viral components can serve as potential molecular targets for ROS, the most readily available are proteins and unsaturated lipids of viral envelopes [13]. As summarized by Costa et al. [14], the main types of photodynamic damage to mammalian virus envelopes include: altering protein cross-link formation, a complete loss of proteins, changes in protein conformation or the alteration of molecular mass and charge. These forms of virion damage can prevent viral absorption and host penetration, inhibit membrane fusion, and reduce infectivity. The kinetics of viral inactivation depends on the photosensitizer concentration, yield of singlet oxygen, and parameters of irradiation $[9,14]$.

Phthalocyanines with intensive absorption at the far red to near-infrared wavelengths are commonly used photosensitizers. Energy migration from the triplet excited state of phthalocyanine to the triplet ground state of molecular oxygen leads to the formation of highly reactive singlet oxygen [15]. Peripherally charged substituents prevent aggregation, greatly improve compatibility of metallophthalocyanines (Me-Pcs) with aqueous media and increase singlet oxygen yield generation up to $0.60-0.65$ values for octa-substituted compounds [16]. Cationic substituted Me-Pcs with long triplet lifetimes, high photostability, and high yields of singlet oxygen are potent antimicrobial photosensitizers against both gram-positive and gram-negative bacteria, pathogenic fungi, and viruses [17-19].

As previously demonstrated in vitro, octacationic octakis(cholinyl) zinc phthalocyanine (Zn-PcChol8+) is highly efficient in disinfecting water from avian influenza A virus, H5N1 subtype [20]. In this instance, photodynamic treatment with Zn-PcChol8+ $(1.0 \mathrm{mg} / \mathrm{L})$ and white light $\left(15 \mathrm{~J} / \mathrm{cm}^{2}\right)$ completely inactivated $\mathrm{H} 5 \mathrm{~N} 1$ in all virus titers tested by up to $7.0 \mathrm{lg}$ EID50, which is more effective compared to methylene blue or proflavine acetate. The singlet oxygen induced inactivation of viral fusion suggested hemagglutinin [9], the viral fusion surface glycoprotein, to be one possible target for photodynamic treatment. Zarubaev et al. [21] showed fragmentation of membranes and loss of surface glycoproteins in H1N1 influenza virus inactivated in allantoic fluid with $0.5 \mathrm{mg} / \mathrm{mL}$ fullerene photosensitizer and $5 \mathrm{~h}$ white light irradiation. However, it remains unclear whether inactivation is due to the loss of glycoproteins or due to oxidative destruction of the virus membrane. Also, long irradiation times in allantoic fluid can cause other side effects yet to be identified. To determine what ultrastructural components of influenza virions are target by PDI, we inactivated highly pathogenic avian H5N8 influenza virus with the photosensitizer Zn-PcChol8 + at different concentrations ( 2 or $4 \mu \mathrm{M}$ that corresponds to 3.2 or $6.4 \mu \mathrm{g} / \mathrm{mL}$ ) with $20 \mathrm{~min}$ white light irradiation and studied the associated morphological changes using a transmission election microscope (TEM).

\section{Materials and Methods}

\subsection{Virus Production and Purification}

Avian influenza A virus A/domestic duck/Siberia/103/2016 (H5N8) was grown in 10-day old embryonated chicken eggs. After incubation at $37^{\circ} \mathrm{C}$ for 3 days, the allantoic fluid was harvested and stored at $-80^{\circ} \mathrm{C}$ until use [22]. All H5N8 experiments were performed according to the standard protocols at the BSL 3 Laboratory (Federal Research Centre fundamental and translational medicine, Novosibirsk, Russia).

Initially, the protocol did not contain a purification step but attempted to observe the effects of PDI using non-purified allantoic fluid. However, the allantoic fluid appears to mask viral particles because of the high concentration of proteins and other biomolecules. Therefore, we used a simple and rapid variation of the purification method developed by [23] for bacteriophages. In brief, the allantoic fluid was filtered through a $0.22 \mu \mathrm{m}$ filter and diluted five times with phosphate-buffered saline (PBS, pH 7.4). Centrifugal concentrators "Vivaspin 6" MWCO 300 kDa (Vivaproducts, Littleton, MA, USA) were filled with the suspension ( $6 \mathrm{~mL}$ per tube) and centrifuged at $4000 \times g$ for $5 \mathrm{~min}$. PBS was then added up to $6 \mathrm{~mL}$ and the concentrators were vigorously mixed and centrifuged again at the same speed and duration as above. This procedure was repeated five times. After the fifth centrifugation step, the suspension was collected from the concentrators (about $1 \mathrm{~mL}$ per tube). This method provides 
high quality purification but leads to a reduction in virus titer (from $8.375 \pm 0.42$ to $7.125 \pm 0.34$ in our preparation) because some virions can get stuck in the membrane [24].

\subsection{Cell Culture and Virus Titration}

Madin Darby Canine Kidney (MDCK) cells were grown at $37{ }^{\circ} \mathrm{C}$ with $5 \% \mathrm{CO}_{2}$ in Eagle minimal essential medium (Thermo Fisher Scientific, Waltham, MA, USA, supplemented with 10\% fetal bovine serum (FBS, Invitrogen) and gentamicin $50 \mu \mathrm{g} / \mathrm{mL}$ (Biolot, St. Petersburg, Russia). After virus inoculation, cells were cultured in Eagle minimal essential medium supplemented with $0.2 \%$ bovine serum albumin (BSA, Biolot), gentamicin $50 \mu \mathrm{g} / \mathrm{mL}$ (Biolot) and $2 \mu \mathrm{g} / \mathrm{mL}$ of trypsin (Sigma-Aldrich, St. Louis, MO, USA). In all experiments, cells that were not infected with the virus were included as controls.

For virus titration, MDCK cells were grown to $90 \%$ confluency in 96-well plates, then washed with PBS and infected with 10-fold serial dilutions (from 10-1 to 10-8) of the treated or non-treated virus. After incubating for $30 \mathrm{~min}$ at $37^{\circ} \mathrm{C}$, the supernatant was removed and cells were incubated with $200 \mu \mathrm{L}$ of virus growth medium at $37{ }^{\circ} \mathrm{C}, 5 \% \mathrm{CO}_{2}$ for 5 days. Virus-induced cytopathic effect was detected and virus titers were determined as the $50 \%$ tissue culture infectious dose (TCID50) per $\mathrm{ml}$ according to Reed and Muench [25]. To prevent accidental irradiation of samples containing photosensitizer, the plates were protected from light with aluminum foil.

Singlet oxygen is a nonradical reactive oxygen species that readily oxidizes aromatic amino acids, unsaturated lipids and other biomolecules, and has the extremely short lifetime (about $1 \mu \mathrm{s}$ ) in biological systems [26]. It seems unlikely that traces of singlet oxygen could be detected after photodynamic treatment which could negatively impact MDCK cells. Moreover, MDCK cells were infected with 10 -fold dilutions (from $10^{-1}$ to $10^{-8}$ ) of treated virus which further minimizes the effect of residual products of photodynamic reaction.

\subsection{Photodynamic Inactivation}

Zn-PcChol8+ synthesized in the State Scientific Center "NIOPIK" (Russia) was used as a photosensitizing agent for virus inactivation in two treatments corresponding to concentrations of either 2 or $4 \mu \mathrm{M}$. The irradiation system was constructed from $30 \mathrm{~W}$ halogen lamp with collimated light beam (12 mm diameter). Virus suspensions (1 mL) were irradiated in opened $1.5 \mathrm{~mL}$ "Eppendorf" vials for 20 min at light dose of $12 \mathrm{~J} / \mathrm{cm}^{2}$. The intensity of light reaching the probes was measured with PM160T Wireless Power Meter (THORLABS GmbH, Dachau, Germany) and made up $10 \mathrm{~mW} / \mathrm{cm}^{2}$. The vial containing the virus suspension was then placed in a plastic water filled box to prevent overheating. In addition, we included two control treatments: dark (incubated in the dark with photosensitizer) and light (irradiated as above without photosensitizer).

\subsection{Electron Microscopy}

A 200 mesh copper TEM grid (SPI Supplies, West Chester, PA, USA) with carbon stabilized ultrathin (invisible on the water surface) [27] formvar support film was placed on a $10 \mu$ droplet of suspension for $30 \mathrm{~s}$ and then dried using filter paper. A $10 \mu \mathrm{l}$ droplet of uranyl acetate water solution $(1 \% w / v)$ was then added to the grid surface for $15 \mathrm{~s}$. After drying, using filter paper again, the grid was examined with a TEM (JEM-1400; Jeol, Japan) at an accelerating voltage of $80 \mathrm{kV}$.

Three TEM grids per sample were prepared independently to avoid random artefacts. At least 100 virions were examined in each sample. To prevent accidental irradiation, the preparation of the dark control was conducted in a dark room. 


\section{Results}

\subsection{Purified and Non-Purified Allantoic Fluid Comparison}

Using a non-purified allantoic liquid with $2 \mu \mathrm{M}$ of photosensitizer proved to be inadequate because it was difficult to observe any structural features. This is likely due to the high concentration of proteins and other biomolecules within allantoic fluid which mask the virions. In addition, these molecules react with the singlet oxygen produced by the photosensitizer. TEM images revealed that purification of the allantoic fluid dramatically improved the visibility of virion structures (Figure 1). The concentrator-based virus purification technique is faster and easier compared with classical ultracentrifugation-based protocols and produced pure high-quality viral samples with intact virions. Thus, non-purified allantoic fluid cannot be used for ultrastructural examination of influenza virus after photodynamic inactivation and it is necessary to purify the virus suspension for accurate visualization.

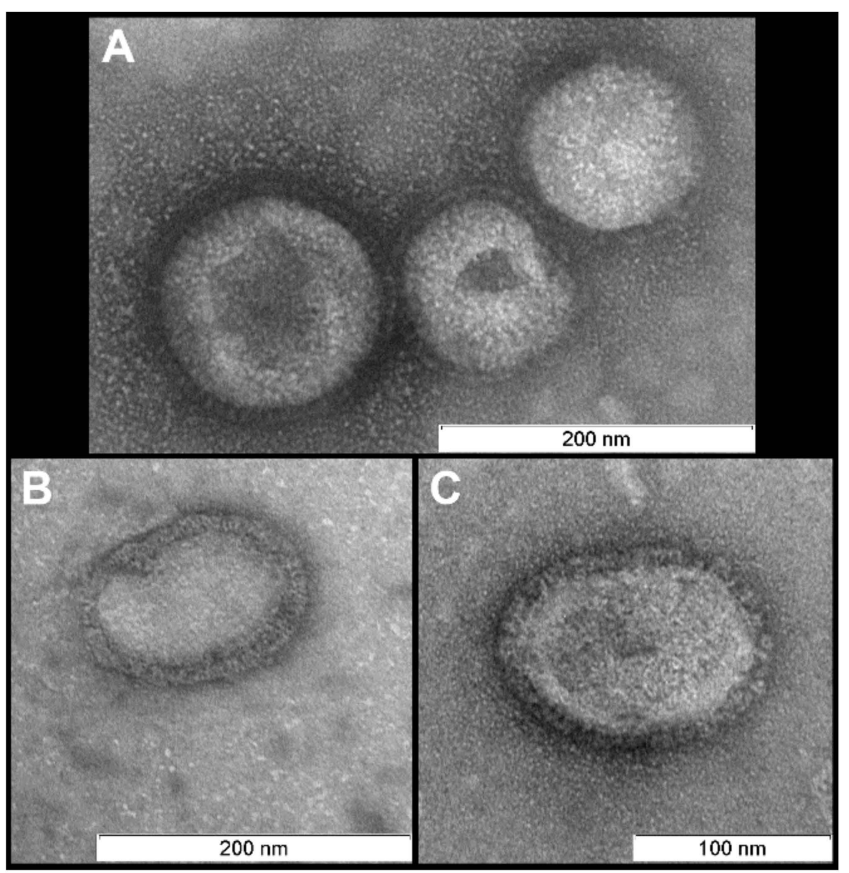

Figure 1. Virions after purification. Morphology is typical for influenza virus: near-spherical enveloped virions (diameter 100-130 nm) with spikes. Scale bar $200 \mathrm{~nm}(\mathbf{A}, \mathbf{B})$ and $100 \mathrm{~nm}(\mathbf{C})$.

\subsection{H5N8 Photodynamic Inactivation and Infectivity}

Five samples of H5N8 influenza virus were examined with a TEM under different conditions:

- $\quad$ purified suspension without any treatment (Figure 1);

- $\quad$ irradiated without photosensitizer (light control, Figure 2);

- $\quad$ not irradiated (dark control) suspension with $4 \mu \mathrm{M}$ of the photosensitizer (Figure 3);

- $\quad$ irradiated with photosensitizer at concentrations of $2 \mu \mathrm{M}$ (Figure 4);

- $\quad$ irradiated with photosensitizer at concentrations of $4 \mu \mathrm{M}$ (Figures 5 and 6).

There were no differences in viral morphology between untreated virions or light and dark controls (Figures 1-3). 


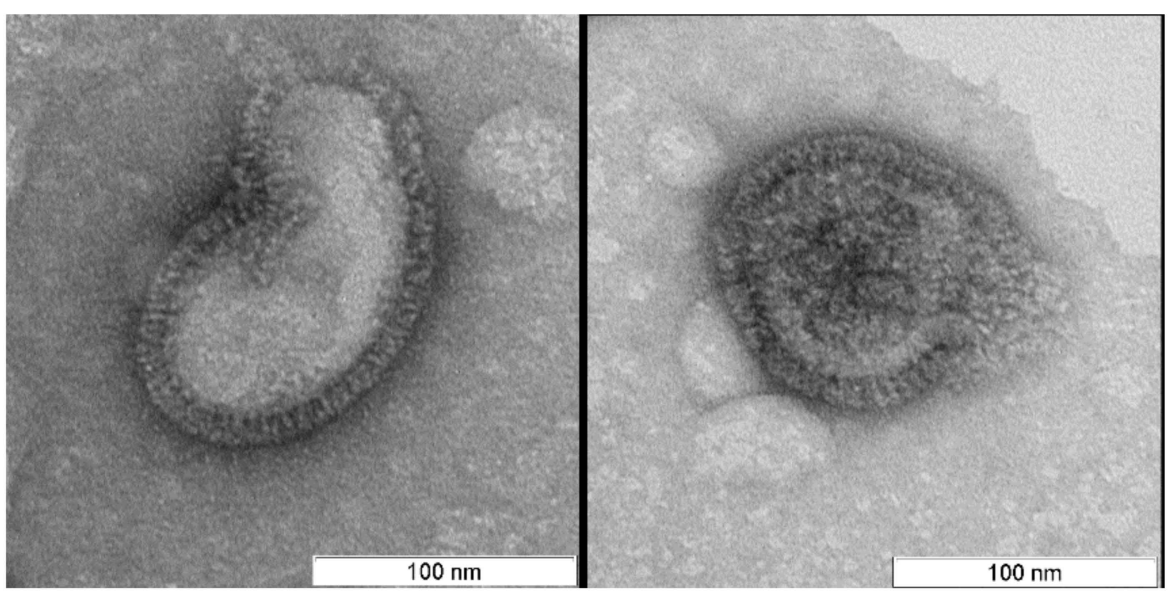

Figure 2. Light control. Virions look intact. Scale bar $100 \mathrm{~nm}$.

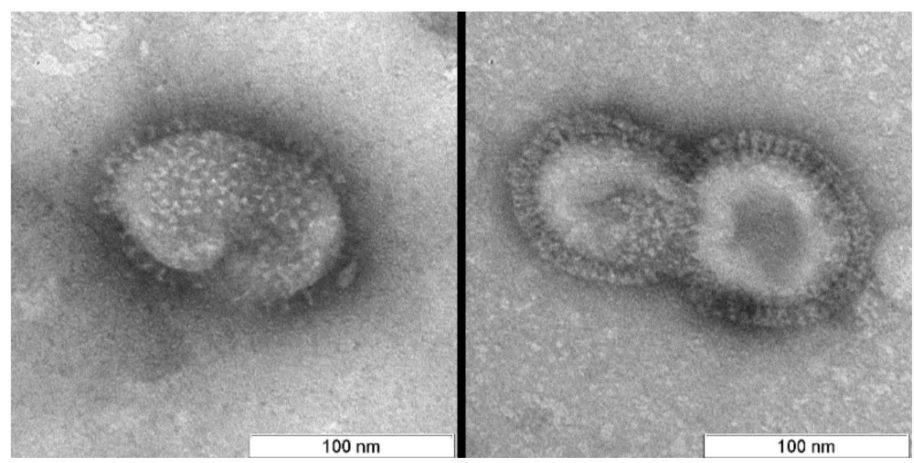

Figure 3. Dark control. Virions look intact. Scale bar 100 nm.

In contrast to the controls, virions irradiated with photosensitizer were damaged (Figures 4-6). Virions were completely inactivated (Table 1$)$ for both photosensitizer concentrations ( 2 and $4 \mu \mathrm{M})$ and all lost their surface glycoproteins (spikes). Virions inactivated with $2 \mu \mathrm{M}$ of the photosensitizer became "bald", but their membranes appeared to maintain structural integrity and were coated with a "halo", which can point to non-complete oxidative destruction of the glycoproteins (Figure 4). Evidence for the maintenance of membrane structural integrity is given in Figure 4 which shows virions keeping their normal near-spherical shape and remaining impermeable to the negative stain [28]. We also observed smooth spherical vesicles and small grain-like structures when using photosensitizer ( 2 and $4 \mu \mathrm{M}$ concentrations: Figures 4-6) which were not present in the controls (Figure 7). 


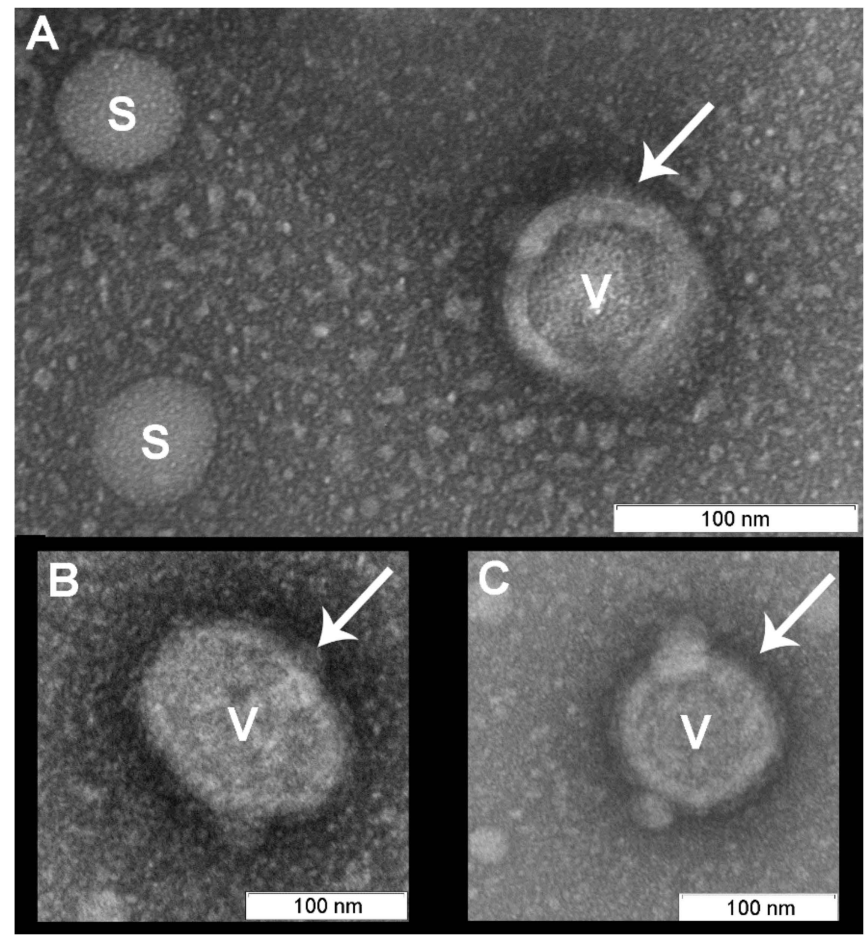

Figure 4. Virions (“V”) irradiated for $20 \mathrm{~min}$ with photosensitizer $(2 \mu \mathrm{M})$ remained structurally normal with membranes maintaining their structural integrity. The spikes appeared to be absent from the viral membranes, however the "halo" may indicate the presence of glycoproteins (marked with arrows). Spherical vesicles (diameter 30-50 nm, marked "S" (A), the similar structures can be recognized on virions surface (B, C)) and grain-like small (5-15 nm) structures were visible and were not observed in the controls. Scale bar $100 \mathrm{~nm}$.

The virus suspension inactivated with $4 \mu \mathrm{M}$ of photosensitizer contained three forms of "bald" virions: smooth spherical virus particles ( $25 \%$ of examined virions), virions with partially destroyed membranes ("dark windows", $\sim 60 \%$ ), and completely (deformed, disintegrated particles, $\sim 15 \%$ ) destroyed membranes (Figures 5 and 6 ). These forms seem to reflect the degree of virion damage and may be associated with both irradiation fluctuations and the heterogeneity of virions with respect to photosensitizer binding. Long periods of irradiation with high concentrations of photosensitizer destroyed all virions as shown in other studies [21].

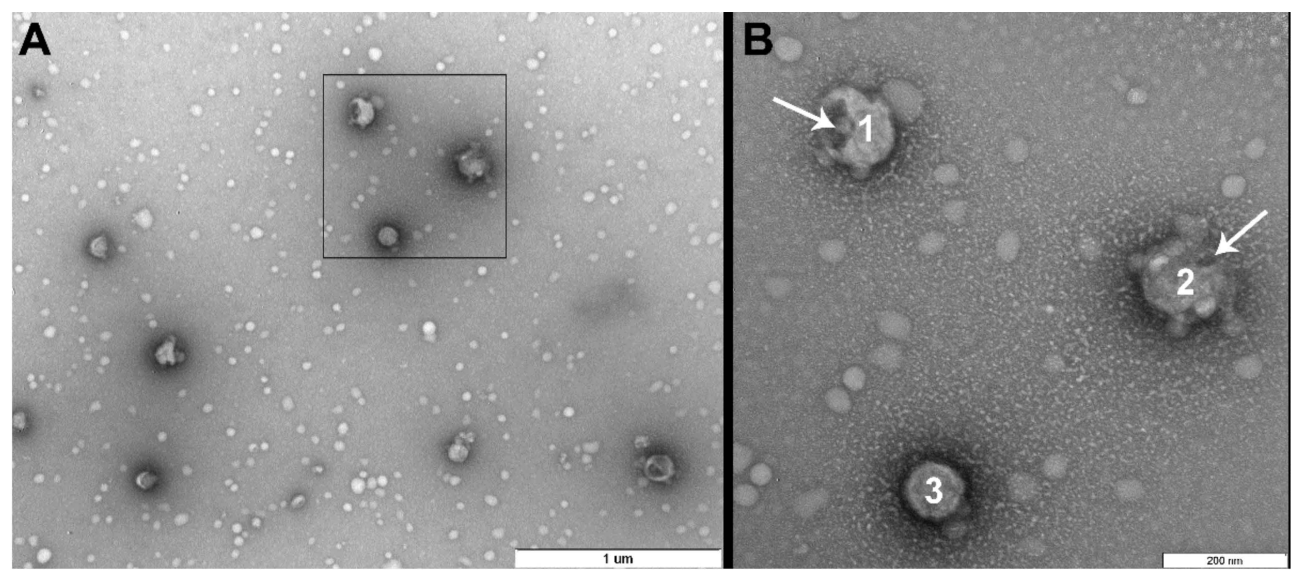

Figure 5. Virions after photodynamic inactivation (PDI) (4 $\mu \mathrm{M}$ photosensitizer). (A) Low magnification (scale bar $1 \mu \mathrm{m}$ ); (B) Magnified area denoted by black box in (A) (scale bar $200 \mathrm{~nm}$ ). It is possible to distinguish two different forms of "bald" virus particles: smooth spherical virions (" 3 ") and virions with damaged membranes ("1" and "2"). Membrane damage or "dark windows" are marked with arrows. 


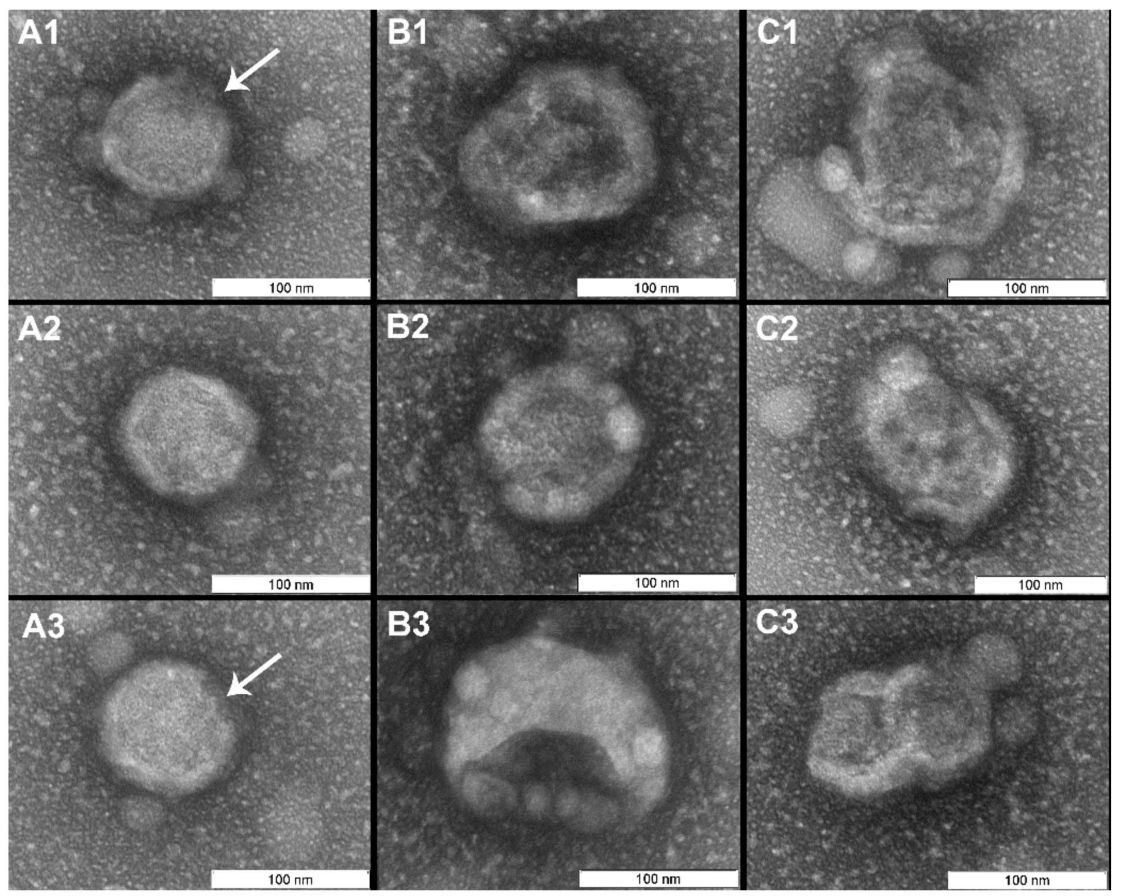

Figure 6. Virions after PDI ( $4 \mu \mathrm{M}$ photosensitizer). All virus particles are "bald". Columns are organized according to the condition of the lipid membranes: (A) membranes maintained structural integrity, minor membrane damages marked with arrows; (B) virions with partially destroyed membranes; (C) membranes are destroyed and virions disintegrated. Scale bar $100 \mathrm{~nm}$.

Virus titer was determined by a virus titration using MDCK cells. The virus titration showed that the titers of non-treated purified virions and controls were similar (Table 1). The titer decreasing by purification can be explained by the loss of the virions in the centrifugal concentrator pores. In samples irradiated with photosensitizer (both concentrations), complete inactivation was achieved (Table 1). This suggests that even the "bald" virions with membrane integrity maintained are non-infectious and that a complete loss of virion integrity is not necessary for virus inactivation. This finding implies that PDI can be used for manufacturing "bald" virions which are non-infectious but likely maintain structural membrane integrity and RNA.

Table 1. Determination of virus titers by virus titration on Madin Darby Canine Kidney (MDCK) cells. It has been shown that 20 min irradiation with photosensitizer (PS) leads to the total inactivation of the virus.

\begin{tabular}{ccccccc}
\hline Titer of Virus & Allantoic Fluid & $\begin{array}{c}\text { Purified } \\
\text { Suspension }\end{array}$ & $\begin{array}{c}\text { Stored in } \\
\text { Dark with PS } \\
\mathbf{( 4 \mu M )}\end{array}$ & $\begin{array}{c}\text { Irradiated } \\
\text { for 20 Min } \\
\text { without PS }\end{array}$ & $\begin{array}{c}\text { Irradiated for } \\
\text { 20 Min with PS } \\
(\mathbf{2} \boldsymbol{\mu M})\end{array}$ & $\begin{array}{c}\text { Irradiated for } \\
\mathbf{2 0} \text { Min with PS } \\
\mathbf{( 4} \boldsymbol{\mu M})\end{array}$ \\
\hline $\lg \mathrm{MCID} 50 / \mathrm{mL} \pm 26$ & $8.375 \pm 0.42$ & $7.125 \pm 0.34$ & $7.25 \pm 0.30$ & $7.0 \pm 0.42$ & 0 & 0 \\
\hline
\end{tabular}

On the micrographs of both ( 2 and $4 \mu \mathrm{M}$ of photosensitizer) photodynamically treated samples smooth spherical vesicles $(30-50 \mathrm{~nm})$ and small $(5-15 \mathrm{~nm})$ grain-like structures have been detected (Figure 4). Concentration of both types of structures is higher in the sample irradiated with $4 \mu \mathrm{M}$ of photosensitizer. Such structures were not presented in controls (Figure 7). 


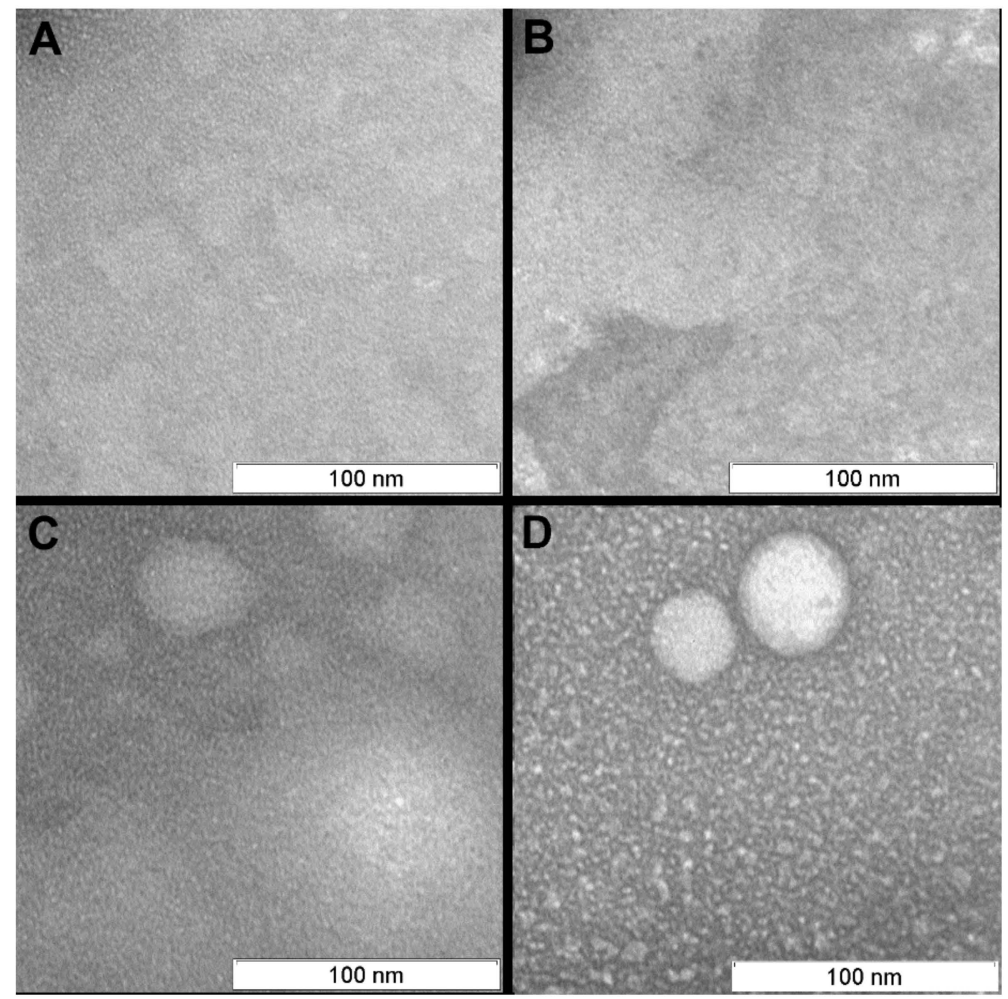

Figure 7. Background of the transmission electron microscopy (TEM) pictures (area between virions). (A) Purified virus suspension; (B) Light control; (C) Dark control; (D) After photodynamic inactivated (4 $\mu \mathrm{M}$ photosensitizer, $20 \mathrm{~min}$ ). Scale bar $100 \mathrm{~nm}$.

\section{Discussion}

Here, we investigated the ultrastructural properties of photodynamic inactivation of H5N8 influenza virus. We demonstrate that PDI treatment of the virus induces the removal of viral surface glycoproteins and makes virions non-infectious even without membrane damage. Because proteins are readily oxidized by singlet oxygen [13], hemagglutinin, the viral fusion surface glycoprotein, might be particularly susceptible to the singlet oxygen produced by PDI. Overall, three distinct forms of virion damage were induced by photodynamic inactivation. We observed "bald" virions with membranes keeping structural integrity, virions with damaged membranes and virions that were totally destroyed (Figure 8). We show that all three forms are non-infectious (Table 1).

In this study, the treatment with the photosensitizer Zn-PcChol8+ (2 or $4 \mu \mathrm{M})$ and $20 \mathrm{~min}$ white light irradiation (light dose $12 \mathrm{~J} / \mathrm{cm}^{2}$ ) rendered $\mathrm{H} 5 \mathrm{~N} 8$ virions unable to infect MDCK cells. Such a strong inactivation effect with this octacationic phthalocyanine photosensitizer is not unique to the influenza virus H5N8 as it has been previously shown for the H5N1 subtype [20]. Another tricationic phthalocyanine inactivated H1N1 with IC50 value $0.087 \mathrm{nM}$ [18] after 20 min red light illumination (light dose $48 \mathrm{~J} / \mathrm{cm}^{2}$ ). Thus, cationic phthalocyanines are highly active photosensitizers towards influenza viruses.

"Bald" influenza virions were first described by Brand and Skehel in 1972 [29] and were created using a protease treatment (bromelain). Bromelain enzymatically detaches ectodomains of hemagglutinins which in the untreated viruses form spikes protruding from the membrane surface. On negatively stained electron micrographs, bromelain treated virions generally appear smooth with no visible spikes [30]. A similar pattern was observed in this study (Figures 4-6), whereby irradiated H5N8 virions treated with Zn-PcChol8+ appeared "bald". This suggests that ROSs can detach spike glycoproteins. Such "bald" virus particles can be used in studies of biophysical properties of virions (e.g., remove surface glycoproteins to estimate their influence on virion stiffness [30]) and in viral engineering. 
The smooth vesicles and small grain-like structures detected in the photodynamically treated samples can be formed from detached virus subunits. Such structures were not presented in control samples. The vesicles looked similar to structures found on the H3N2 viral particles exposed in acid medium [31]. The "bald" virions were larger and had a stained dark core, thus they appear distinct from the smooth round vesicles on the micrographs.

Using a high photosensitizer concentration $(4 \mu \mathrm{M})$, we observed irregular virion shapes which likely reflect virion membrane damage. One explanation is that the hydroperoxides of cholesterol and other lipids disrupt viral membranes [32] and induce lipid membrane damage.

In conclusion, influenza virus in our experiments was inactivated with singlet oxygen that was generated by the photoexcited phthalocyanine photosensitizer. Furthermore, our results demonstrate that the detachment of the influenza virus surface glycoproteins and the loss of infectivity by "bald" virions was the result of the photodynamic treatment. This type of viral inactivation may be representative for other sources of singlet oxygen. Indeed, the highly reactive ROS produced by chemical reactions in the dark [33] and even by immune cells during oxidative burst [34] also exhibits viricidal properties.

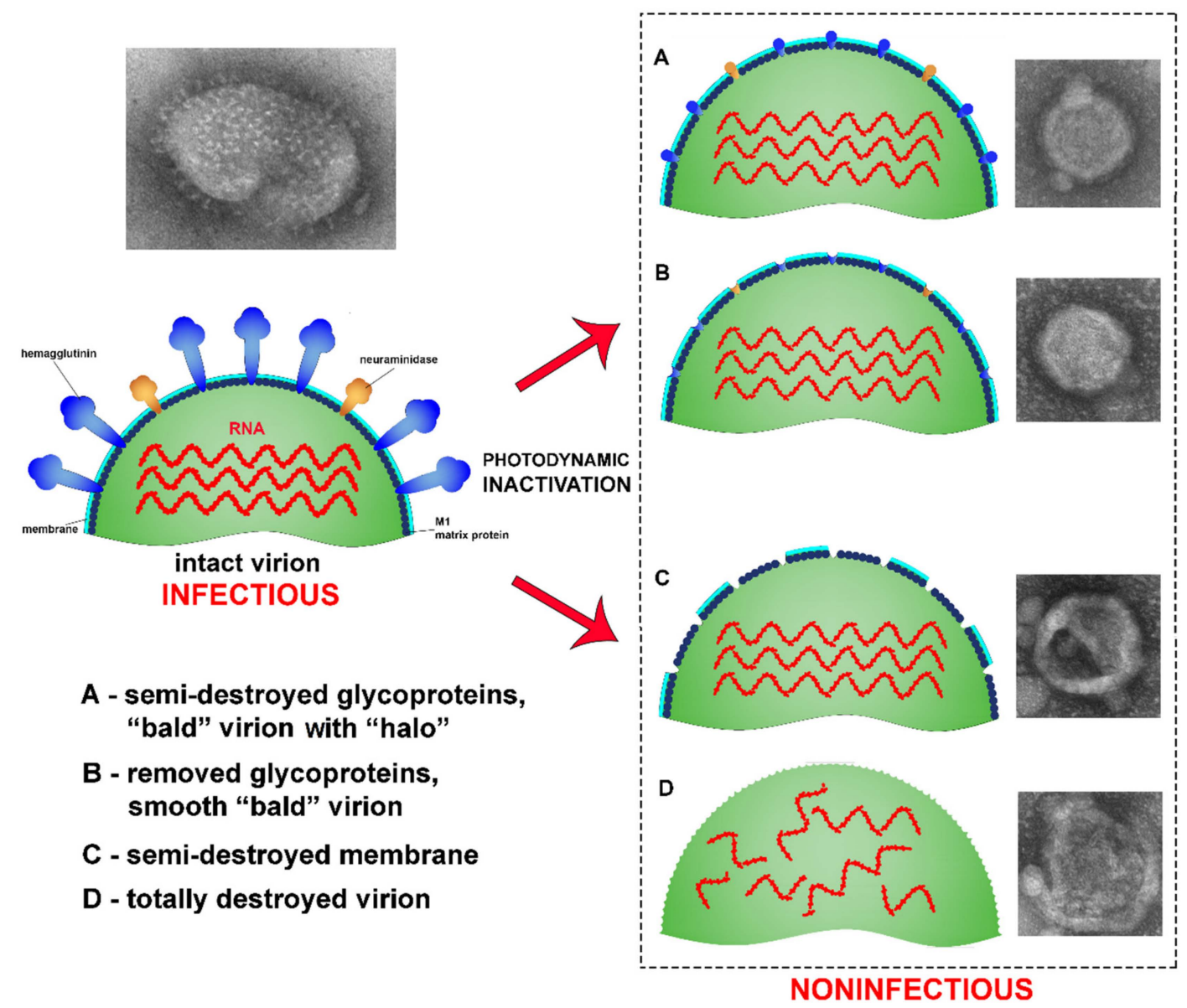

Figure 8. An illustration of the effects photodynamic inactivation has on influenza virus. (A) semi-destroyed glycoproteins;(B) removed glycoproteins; (C) Partial membrane destruction; (D) Total virion destruction.

Author Contributions: Conceptualization, D.K., J.E. and M.S.; methodology, D.K. and M.S.; investigation, D.K., O.K., K.S.; writing — original draft preparation, D.K., M.S.; writing—review and editing, J.E., M.S.; visualization, D.K.; supervision, M.S.; funding acquisition, K.S.

Funding: This study was supported by a grant of Russian Scientific Foundation [project number 17-44-07001]. 
Acknowledgments: The authors are deeply grateful to Yuzhakova O.A. for providing the photosensitizer octakis (cholinyl) zinc phthalocyanine. We would like to thank three anonymous reviewers for their helpful insights which greatly improved the manuscript.

Conflicts of Interest: The authors declare no conflict of interest.

\section{References}

1. Jori, G.; Brown, S.B. Photosensitized inactivation of microorganisms. Photochem. Photobiol. Sci. 2004, 3, 403-405. [CrossRef] [PubMed]

2. Kharkwal, G.B.; Sharma, S.K.; Huang, Y.Y.; Dai, T.; Hamblin, M.R. Photodynamic therapy for infections: Clinical applications. Lasers Surg. Med. 2011, 43, 755-767. [CrossRef] [PubMed]

3. Wainwright, M. Photoinactivation of viruses. Photochem. Photobiol. Sci. 2004, 3, 406-411. [CrossRef] [PubMed]

4. Marotti, J.; Aranha, A.C.; Eduardo, C.P.; Ribeiro, M.S. Photodynamic therapy can be effective as a treatment for herpes simplex labialis. Photomed. Laser Surg. 2009, 27, 357-363. [CrossRef] [PubMed]

5. Ryberg, E.C.; Chu, C.; Kim, J.H. Edible Dye-Enhanced Solar Disinfection with Safety Indication. Environ. Sci. Technol. 2018, 52, 13361-13369. [CrossRef]

6. Trannoy, L.L.; Lagerberg, J.W.; Dubbelman, T.M.; Schuitmaker, H.J.; Brand, A. Positively charged porphyrins: A new series of photosensitizers for sterilization of RBCs. Transfusion 2004, 44, 1186-1196. [CrossRef]

7. Wagner, S.J.; Robinette, D.; Storry, J.; Chen, X.Y.; Shumaker, J.; Benade, L. Differential sensitivities of viruses in red cell suspensions to methylene blue photosensitization. Transfusion 1994, 34, 521-526. [CrossRef]

8. O'Brien, J.M.; Gaffney, D.K.; Wang, T.P.; Sieber, F. Merocyanine 540-sensitized photoinactivation of enveloped viruses in blood products: Site and mechanism of phototoxicity. Blood 1992, 80, 277-285.

9. Lenard, J.; Rabson, A.; Vanderoef, R. Photodynamic inactivation of infectivity of human immunodeficiency virus and other enveloped viruses using hypericin and rose bengal: Inhibition of fusion and syncytia formation. Proc. Natl. Acad. Sci. USA 1993, 90, 158-162. [CrossRef]

10. Vzorov, A.N.; Dixon, D.W.; Trommel, J.S.; Marzilli, L.G.; Compans, R.W. Inactivation of human immunodeficiency virus type 1 by porphyrins. Antimicrob. Agents Chemother. 2002, 46, 3917-3925. [CrossRef]

11. Smetana, Z.; Ben-Hur, E.; Mendelson, E.; Salzberg, S.; Wagner, P.; Malik, Z. Herpes simplex virus proteins are damaged following photodynamic inactivation with phthalocyanines. J. Photochem. Photobiol. B Biol. 1998, 44, 77-83. [CrossRef]

12. Sobotta, L.; Wierzchowski, M.; Mierzwicki, M.; Gdaniec, Z.; Mielcarek, J.; Persoons, L.; Goslinski, T.; Balzarini, J. Photochemical studies and nanomolar photodynamic activities of phthalocyanines functionalized with 1,4,7-trioxanonyl moieties at their non-peripheral positions. J. Inorg. Biochem. 2016, 155, 76-81. [CrossRef] [PubMed]

13. Davies, M.J. Reactive species formed on proteins exposed to singlet oxygen. Photochem. Photobiol. Sci. 2004, 3, 17-25. [CrossRef] [PubMed]

14. Costa, L.; Faustino, M.A.F.; Neves, M.G.P.M.S.; Cunha, A.; Almeida, A. Photodynamic Inactivation of Mammalian Viruses and Bacteriophages. Viruses 2012, 4, 1034-1074. [CrossRef]

15. Spikes, J.D. Phthalocyanines as photosensitizers in biological systems and for the photodynamic therapy of tumors. Photochem. Photobiol. 1986, 43, 691-699. [CrossRef]

16. Makarov, D.A.; Kuznetsova, N.A.; Yuzhakova, O.A.; Savvina, L.P.; Kaliya, O.L.; Lukyanets, E.A.; Negrimovskii, V.M.; Strakhovskaya, M.G. Effects of the degree of substitution on the physicochemical properties and photodynamic activity of zinc and aluminum phthalocyanine polycations. Russ. J. Phys. Chem. A 2009, 83, 1044-1050. [CrossRef]

17. Minnock, A.; Vernon, D.I.; Schofield, J.; Griffiths, J.; Parish, J.H.; Brown, S.T. Photoinactivation of bacteria. Use of a cationic water-soluble zinc phthalocyanine to photoinactivate both gram-negative and gram-positive bacteria. J. Photochem. Photobiol. B 1996, 32, 159-164. [CrossRef]

18. Ke, M.R.; Eastel, J.M.; Ngai, K.L.; Cheung, Y.Y.; Chan, P.K.; Hui, M.; Ng, D.K.; Lo, P.C. Photodynamic inactivation of bacteria and viruses using two monosubstituted zinc(II) phthalocyanines. Eur. J. Med. Chem. 2014, 84, 278-283. [CrossRef]

19. Li, X.S.; Guo, J.; Zhuang, J.J.; Zheng, B.Y.; Ke, M.R.; Huang, J.D. Highly positive-charged zinc(II) phthalocyanine as non-aggregated and efficient antifungal photosensitizer. Bioorg. Med. Chem. Lett. 2015, 25, 2386-2389. [CrossRef] 
20. Kuznetsova, N.; Kaliya, O.; Strakhovskaya, M.; Zubairov, M. Photodynamic inactivation of avian influenza virus in aqueous media. In Proceedings of the First International Workshop on Application of Redox Technologies in the Environment 2009, Istanbul, Turkey, 14-15 September 2009; pp. 145-147.

21. Zarubaev, V.V.; Belousova, I.M.; Kiselev, O.I.; Piotrovsky, L.B.; Anfimov, P.M.; Krisko, T.C.; Muraviova, T.D.; Rylkov, V.V.; Starodubzev, A.M.; Sirotkin, A.C. Photodynamic inactivation of influenza virus with fullerene C60 suspension in allantoic fluid. Photodiagnosis Photodyn Ther. 2007, 4, 31-35. [CrossRef]

22. Stear, M.J. OIE Manual of Diagnostic Tests and Vaccines for Terrestrial Animals (Mammals, Birds and Bees), 5th ed.; Cambridge University Press: Cambridge, UK, 2004; 588p, ISBN 92-9044-622-6.

23. Bonilla, N.; Rojas, M.I.; Cruz, G.N.F.; Hung, S.-H.; Rohwer, F.; Barr, J.J. Phage on tap-A quick and efficient protocol for the preparation of bacteriophage laboratory stocks. PeerJ 2016, 4, e2261. [CrossRef] [PubMed]

24. Zaitsev, B.N.; Taranov, O.S.; Rudometova, N.B.; Shcherbakova, N.S.; Ilyichev, A.A.; Karpenko, L.I. An optimized method for counting viral particles using electron microscopy. Vavilov J. Genet. Breed. 2019, 23, 337-342. [CrossRef]

25. Reed, L.J.; Muench, H. A simple method of estimating fifty per cent endpoints. Am. J. Epidemiol. 1938, 27, 493-497. [CrossRef]

26. Li, B.; Lin, L.; Lin, H.; Wilson, B.C. Photosensitized singlet oxygen generation and detection: Recent advances and future perspectives in cancer photodynamic therapy. J. Biophotonics 2016, 11-12, 1314-1325. [CrossRef] [PubMed]

27. Davison, E.; Colquhoun, W.J. Ultrathin Formvar Support Films for Transmission Electron Microscopy. Electron Microsc. Tech. 1985, 2, 35-43. [CrossRef]

28. Scarff, C.A.; Fuller, M.J.G.; Thompson, R.F.; Iadaza, M.G. Variations on Negative Stain Electron Microscopy Methods: Tools for Tackling Challenging Systems. J. Vis. Exp. 2018, 132, e57199. [CrossRef] [PubMed]

29. Brand, C.M.; Skehel, J.J. Crystalline antigen from the influenza virus envelope. Nat. New Biol. 1972, 238, 145-147. [CrossRef]

30. Schaap, I.A.; Eghiaian, F.; des Georges, A.; Veigel, C. Effect of envelope proteins on the mechanical properties of influenza virus. J. Biol. Chem. 2012, 287, 41078-41088. [CrossRef]

31. Zhirnov, O.P.; Manykin, A.A. Abnormal Morphological Vesicles in Influenza A Virus Exposed to Acid pH. Bull. Exp. Biol. Med. 2015, 158, 776-780. [CrossRef]

32. Girotti, A.W.; Korytowski, W. Cholesterol Peroxidation as a Special Type of Lipid Oxidation in Photodynamic Systems. Photochem. Photobiol. 2019, 95, 73-82. [CrossRef]

33. Müller-Breitkreutz, K.; Mohr, H.; Briviba, K.; Sies, H. Inactivation of viruses by chemically and photochemically generated singlet molecular oxygen. J. Photochem. Photobiol. B 1995, 30, 63-70. [CrossRef]

34. Stief, T.W. The physiology and pharmacology of singlet oxygen. Med. Hypotheses 2003, 60, 567-572. [CrossRef] 